\title{
Taxonomic Position of Lecithinase-negative Strains of Clostridium sordellii
}

\author{
By MICHEL R. POPOFF, ${ }^{1}{ }^{*}$ JEAN-PIERRE GUILLOU ${ }^{2}$ AND \\ JEAN-PHILIPPE CARLIER ${ }^{1}$ \\ 1 Unité des Anaérobies, Institut Pasteur, 25 rue du Docteur Roux, 75724 Paris Cedex 15, France \\ 2 Laboratoire Central de Recherches Vétérinaires, Maisons-Alfort 94701, France
}

(Received 21 December 1984; revised 26 February 1985)

\begin{abstract}
Eleven out of 43 strains of Clostridium sordellii from clinical sources did not produce lecithinase activity and were not toxic to mice. However, these strains did belong to the $C$. sordellii group and could readily be differentiated from $C$. bifermentans and $C$. difficile on the basis of DNADNA homologies, carbohydrate fermentation patterns, enzyme activities, GLC analysis of fatty acid fermentation products and the electrophoretic analysis of whole cell protein extracts.
\end{abstract}

\section{INTRODUCTION}

Clostridium sordellii is commonly encountered in soil and sewage, and in the large bowel of mammals (Willis, 1977). C. sordellii is closely related to C. bifermentans, and these two species are usually clustered in the so-called 'lecithinase-producing Clostridium group' (Holdeman et al., 1977). However, pathogenic and non-pathogenic $C$. sordellii strains can be differentiated from C. bifermentans strains by several phenotypic characters (Brooks \& Epps, 1958; Nishida et al., 1964; Novotny, 1969; Tataki \& Huet, 1953) and by DNA-DNA homology (Nakamura et al., 1975, 1976). On the other hand, $C$. sordellii and $C$. bifermentans strains exhibit marked serological cross-reactions with $C$. difficile, a well-known lecithinase-negative species (Poxton \& Byrne, 1981, 1984; Rifkin et al., 1977).

Recently we have isolated from clinical sources 11 lecithinase-negative strains of Clostridium which display the main phenotypic traits of $C$. sordellii. Because lecithinase activity is an important diagnostic test for $C$. sordellii, the unclear taxonomic position of the isolates led us to attempt the present study.

\section{METHODS}

Bacterial strains. The origins of the 50 strains included in this study are presented in Table 1 . Four strains $(C$. sordellii NCIB 10717 and IP82; C. bifermentans ATCC 638; C. difficile ATCC 9689) are type or reference strains from international collections (Skerman et al., 1980).

Media and growth conditions. Strains were normally grown in TYG broth, containing ( $\left.\mathrm{g}^{-1}\right)$ : trypticase (BBL), 30 ; yeast extract (Difco), 20; glucose 0.5 ; cysteine, $1 ; \mathrm{pH} 7 \cdot 2$. In some experiments, TY broth (TYG broth without glucose) or peptone broth (meat pancreatic peptone (Osi, Paris, France), $20 \mathrm{~g} \mathrm{l}^{-1} ; \mathrm{NaCl}, 5 \mathrm{~g} \mathrm{l}^{-1} ; \mathrm{pH} \mathrm{7.2)} \mathrm{and}$ complex meat/yeast extract agar medium (Beerens, 1954) were used.

All cultures were incubated at $35^{\circ} \mathrm{C}$ in anaerobic jars (Baird and Tatlock) containing a hydrogen atmosphere and a palladium catalyst.

Biochemical studies. Strains received in our laboratory were assigned either to $C$. sordellii (41 strains) or to $C$. bifermentans ( 5 strains) as recommended by Sebald \& Brefort (1977). Sugar fermentation studies were performed in TY broth supplemented with the appropriate carbohydrate $(1 \%, \mathrm{w} / \mathrm{v})$ inoculated with a $2 \%(\mathrm{v} / \mathrm{v})$ dilution in TY broth of an overnight culture in TYG broth. After overnight incubation at $35^{\circ} \mathrm{C}$, the reaction was scored positive if the $\mathrm{pH}$ was below $5 \cdot 5$, and weak if the $\mathrm{pH}$ was between $5 \cdot 5$ and $5 \cdot 7$.

Enzyme activities. Lecithinase activity was determined on Columbia agar (Oxoid) supplemented with $1 \%(\mathrm{v} / \mathrm{v})$ egg yolk. Strains were scored lecithinase negative if no opacity was seen after $4 \mathrm{~d}$ incubation, after removal of the colonies. Weak reactions were considered lecithinase positive. Urease activity was studied in $0 \cdot 5 \mathrm{ml}$ 'urée-indole' 
Table 1. Designation and source of the 50 strains of Clostridium

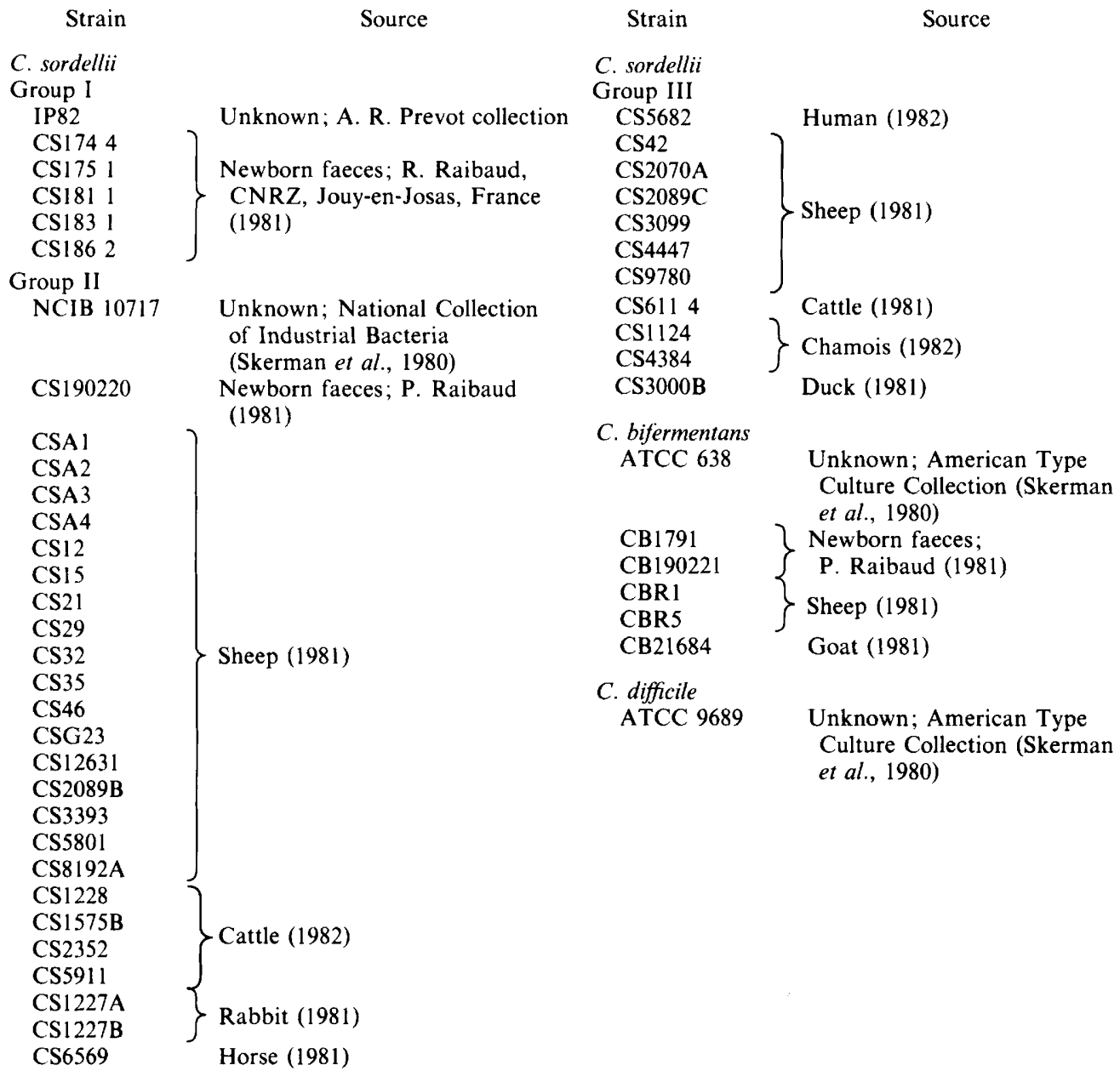

medium (Institut Pasteur Production, Paris). Gelatinase activity was determined in gelatine film-TY broth (Institut Pasteur Production). These three tests and the indole production test were performed as previously described (Sebald \& Brefort, 1977).

Other enzyme activities, reported in Table 3, were detected using API-ZYM galleries (API System). An overnight culture in $5 \mathrm{ml}$ TYG broth was washed once in distilled water and suspended in $1.7 \mathrm{ml} 0.15 \mathrm{M}-\mathrm{NaCl}$. This suspension was used to inoculate each well of the strips. Incubation conditions and reading of results followed the manufacturer's instructions.

Toxicity tests. Supernatant $(0.5 \mathrm{ml})$ from an overnight culture in TYG broth was injected intraperitoneally into 16-20 g male white mice (Swiss) obtained from CESAL (Montmedy, France). Strains were considered toxigenic if the animals died within $3 \mathrm{~d}$ of inoculation.

DNA-DNA homology. Cells from a $500 \mathrm{ml}$ culture in TYG broth incubated anaerobically at $35^{\circ} \mathrm{C}$ for $3 \mathrm{~h}\left(\mathrm{OD}_{600}\right.$ $0.9-1.0)$ were washed with distilled water and suspended in $20 \mathrm{ml} 0.05 \mathrm{M}$-Tris $\mathrm{pH} 8.0$ containing $25 \%(\mathrm{w} / \mathrm{v})$ sucrose and $0.12 \%$ (w/v) lysozyme (Sigma). After incubation at $35^{\circ} \mathrm{C}$ for $1 \mathrm{~h}, 2 \mathrm{ml}$ predigest protease XIV (Sigma; $5 \mathrm{mg} \mathrm{ml}^{-1}$ ) and $16 \mathrm{ml} \mathrm{Sarkosyl} \mathrm{(Ciba-Geigy;} 2 \%, \mathrm{w} / \mathrm{v}$ ) in $0.05 \mathrm{M}$-Tris $/ 0.05 \mathrm{M}$-EDTA pH 8 were added. The mixture was incubated at $35^{\circ} \mathrm{C}$ for $1 \mathrm{~h}$ and $8 \mathrm{ml} 0.25 \mathrm{M}$-EDTA was added. DNA was purified and sheared following established procedures (Brenner et al., 1972).

The DNA from strains NCIB 10717 and ATCC 638, the type strains of C. sordellii and C. bifermentans respectively (Skerman et al., 1980), and from IP82, the laboratory reference strain of pathogenic $C$. sordellii, were labelled in vitro with ${ }^{3} \mathrm{H}$-labelled nucleotides (Grimont et al., 1980).

For DNA base pairing experiments, the S1 nuclease method (Crosa et al., 1973) was used. The DNA duplexes remaining after $\mathrm{S} 1$ nuclease treatment for $30 \mathrm{~min}$ at $45^{\circ} \mathrm{C}$ were separated from free nucleotides by using DEAE- 
cellulose filters (DE81 filters; Whatman) (Popoff \& Coynault, 1980). These DNA-homology studies were performed at optimum renaturation temperature $\left(58^{\circ} \mathrm{C}\right)($ Nakamura et al., 1975) for $18 \mathrm{~h}$. The degree of polynucleotide sequence homology was calculated by determining the ratio between the average counts in the $\mathrm{S}$ treated and untreated samples (Brenner et al., 1976).

SDS-PAGE of cell proteins. Total cell proteins were extracted by a modification of the procedure described by Poxton \& Byrne (1981). Bacteria from $5 \mathrm{ml}$ of an overnight culture in TYG broth were harvested by centrifugation $(5000 \mathrm{~g}, 10 \mathrm{~min})$ and washed in phosphate-buffered saline $(50 \mathrm{mM}$-sodium phosphate buffer, $\mathrm{pH} 7 \cdot 2$, containing $0.15 \mathrm{M}-\mathrm{NaCl}$ ). The pellet was suspended in $0.2 \mathrm{ml} 5 \mathrm{~mm}$-CHES pH 9.8 containing $100 \mathrm{~mm}$-EDTA and incubated for $30 \mathrm{~min}$ at $70{ }^{\circ} \mathrm{C}$. After centrifugation $(5000 \mathrm{~g}, 10 \mathrm{~min})$ the supernatant was retained. The samples were analysed on $12 \%$ polyacrylamide gels containing $0.1 \%(\mathrm{w} / \mathrm{v}) \mathrm{SDS}$ and stained with Coomassie blue according to the method of Laemmli (1970).

GLC. This was done as described by Carlier (1985). The bacteria were grown in TYG broth for $48 \mathrm{~h}$ at $35^{\circ} \mathrm{C}$. A Tracor 560 gas chromatograph (Tracor Instruments) equipped with a flame ionization detector and connected to a model ICR IB integrator (Intersmat France, Suresnes, France) was used. A glass column $(2 \mathrm{~m} \times 4 \mathrm{~mm})$ packed with Resoflex LACIR296 acid-washed on Chromosorb G DMcs (70-80 mesh) was used for volatile fatty acids. The instrument was operated at $125^{\circ} \mathrm{C}$ for $6 \mathrm{~min}$ and then programmed at $20^{\circ} \mathrm{C} \mathrm{min}{ }^{-1}$ to $145^{\circ} \mathrm{C}$. The methyl esters were assayed on a glass column $(2 \mathrm{~m} \times 4 \mathrm{~mm})$ packed with $10 \%(\mathrm{w} / \mathrm{w}) \mathrm{SP} 1000$ (Supelco) containing $1 \%$ (w/w) $\mathrm{H}_{3} \mathrm{PO}_{4}$ acid-washed on Chromosorb W (100-120 mesh). The instrument was operated isothermally at $145^{\circ} \mathrm{C}$. For both assays, the operating conditions were: injector temperature, $200{ }^{\circ} \mathrm{C}$; detector temperature, $250^{\circ} \mathrm{C}$; carrier gas (nitrogen) flow rate, $30 \mathrm{ml} \mathrm{min}^{-1}$. Each peak of the GLC patterns was identified by the retention time compared with those obtained with standards (Merck). The amounts of fatty acids were calculated by comparison with internal standards.

Presentation of data and statistical methods. The data are presented as the mean \pm standard error of the mean and were evaluated statistically by Student's $t$-test.

\section{RESULTS}

\section{Phenotypic characterization}

Forty-three motile, sub-terminal spore-forming, strictly anaerobic strains were identified to C. sordellii on the basis of the following criteria: cell width; motility; Gram-positive character; gelatinase and urease activity; production of indole; fermentation of glucose, fructose, maltose and ribose with the production of gas; lack of hydrolysis of aesculin; production of acetic, propionic, isobutyric, isovalerianic, isocaproic, pyruvic, lactic, phenylacetic and 3-phenylpropionic acids as fermentation end products in TYG broth. None of these strains produced acid from arabinose, dextrin, cellobiose, galactose, inositol, lactose, melezitose, raffinose, rhamnose, saccharose, trehalose or xylose. All the strains showed a similar enzyme activity pattern with API-ZYM tests (Table 2). Three groups were differentiated according to lecithinase reaction and toxigenicity: Group I, 6 lecithinase-positive and toxigenic strains including the reference strain IP82; Group II, 26 lecithinase-positive and non-toxigenic strains including the type strain NCIB 10717; Group III, 11 lecithinase-negative and non-toxigenic strains (Table 3).

The six strains assigned to $C$. bifermentans, including the type strain ATCC 638, showed morphological characters similar to those of the $C$. sordellii strains. However, the sporulation rate in TYG broth was higher than for $C$. sordellii. The $C$. bifermentans strains showed lecithinase and gelatinase activities, were urease negative and non-toxigenic, produced indole, hydrolysed aesculin and fermented glucose, laevulose, maltose, mannose, sorbitol, salicin and aesculin. The type strain $C$. bifermentans ATCC 638 produced only weak acidification from salicin, sorbitol and aesculin when compared to the other $C$. bifermentans strains. All the $C$. bifermentans strains produced enzyme activity patterns with API-ZYM tests, and GLC patterns, similar to those obtained with the $C$. sordellii strains. However, the $C$. bifermentans strains produced more propionic, isocaproic and 3-phenylpropionic acids than the $C$. sordellii strains (Table 4). Two C. bifermentans strains (CB1791 and CB190221) produced low amounts of propionic acid and did not produce lactic acid. Similar amounts of acetic acid were produced by the $C$. sordellii and $C$. bifermentans strains. Isobutyric, isovalerianic, pyruvic, lactic and phenylacetic acids were produced in variable amounts by both these Clostridium species. The characters differentiating $C$. bifermentans strains from $C$. sordellii strains are shown in Tables 3 and 4 . 
Table 2. Enzyme activities of C. sordellii and C. bifermentans strains in API-ZYM tests

\begin{tabular}{|c|c|c|c|c|c|c|c|c|c|c|c|c|c|c|c|c|c|c|c|c|}
\hline \multirow[b]{2}{*}{ Species/group } & \multirow{2}{*}{$\begin{array}{c}\text { No. of strains } \\
\text { tested }\end{array}$} & \multicolumn{19}{|c|}{ No. of strains positive in each enzyme test* } \\
\hline & & A & B & $\mathrm{C}$ & $\mathrm{D}$ & $\mathrm{E}$ & $\mathrm{F}$ & G & $\mathbf{H}$ & I & $\mathrm{J}$ & $\mathrm{K}$ & $\mathrm{L}$ & $\mathbf{M}$ & $\mathbf{N}$ & $\mathrm{O}$ & $\mathbf{P}$ & $Q$ & $\mathbf{R}$ & $\mathrm{S}$ \\
\hline \multicolumn{21}{|l|}{ C. sordellii } \\
\hline Group I & 26 & 26 & 26 & 26 & 0 & 25 & 0 & 7 & 1 & 1 & 26 & 25 & 0 & 4 & 0 & 1 & 0 & 1 & 0 & 1 \\
\hline Group II & 6 & 6 & 6 & 6 & 0 & 5 & 0 & 1 & 0 & 0 & 6 & 6 & 0 & 0 & 0 & 1 & 1 & 1 & 0 & 0 \\
\hline Group III & 11 & 11 & 11 & 11 & 0 & 10 & 0 & 0 & 0 & 0 & 11 & 11 & 1 & 1 & 0 & 1 & 0 & 0 & 0 & 0 \\
\hline \multicolumn{21}{|l|}{ C. bifermentans } \\
\hline & 6 & 6 & 6 & 6 & 0 & 6 & 1 & 3 & 0 & 0 & 6 & 6 & 0 & 0 & 0 & 0 & 1 & 0 & 0 & 0 \\
\hline \multicolumn{21}{|l|}{ C. difficile } \\
\hline & 1 & 1 & 1 & 1 & 0 & 1 & 0 & 0 & 0 & 0 & 0 & 1 & 0 & 0 & 0 & 0 & 0 & 0 & 0 & 0 \\
\hline
\end{tabular}

* A, alkaline phosphatase; B, esterase (C4); C, esterase lipase (C8); D, lipase; E, leucine arylamidase; F, valine arylamidase; $\mathrm{G}$, cystine arylamidase; H, trypsin; I, $\alpha$-chymotrypsin; J, acid phosphatase; K, phosphoamidase; L, $\alpha$-galactosidase; $\mathrm{M}, \beta$-galactosidase; $\mathrm{N}, \beta$-glucuronidase; $\mathrm{O}, \alpha$-glucosidase; $\mathrm{P}, \beta$-glucosidase; $\mathrm{Q}, N$-acetyl- $\beta$ glucosaminidase; $R, \alpha$-mannosidase; $S, \alpha$-fucosidase.

Table 3. Phenotypic differentiation between $C$. sordellii, $C$. bifermentans and $C$. difficile strains

\begin{tabular}{|c|c|c|c|c|c|}
\hline \multirow[b]{2}{*}{ Test } & \multicolumn{3}{|c|}{ C. sordellii } & \multirow[b]{2}{*}{ C. bifermentans } & \multirow[b]{2}{*}{ C. difficile } \\
\hline & Group I & Group II & Group III & & \\
\hline Lecithinase & + & + & - & + & - \\
\hline Mouse toxicity & + & - & - & - & + \\
\hline Urease & & + & & - & - \\
\hline Indole & & + & & + & - \\
\hline Aesculin hydrolysis & & - & & + & + \\
\hline \multicolumn{6}{|l|}{ Fermentation of: } \\
\hline Aesculin & & - & & $+/ w^{*}$ & - \\
\hline Maltose & & + & & + & - \\
\hline Mannose & & - & & + & - \\
\hline Ribose & & + & & + & - \\
\hline Salicin & & - & & $+/ w^{*}$ & - \\
\hline Sorbitol & & - & & $+/ w^{*}$ & - \\
\hline
\end{tabular}

* Strain ATCC 638 gave a weak reaction for these three tests.

Table 4. Quantitative gas liquid chromatography of fermentation products from TYG differentiating $C$. sordellii from $C$. bifermentans

The results are mean concentrations (mM) in the culture supernatant, \pm SEM.

\begin{tabular}{|c|c|c|c|}
\hline $\begin{array}{l}\text { Species/group } \\
\text { (no. of strains) }\end{array}$ & $\begin{array}{l}\text { Propionic } \\
\text { acid }\end{array}$ & $\begin{array}{l}\text { Isocaproic } \\
\text { acid }\end{array}$ & $\begin{array}{l}\text { 3-Phenylpropionic } \\
\text { acid }\end{array}$ \\
\hline \multicolumn{4}{|l|}{ C. sordellii } \\
\hline Group I (4) & $3 \cdot 20 \pm 0 \cdot 35$ & $\begin{array}{l}7 \cdot 80 \pm 0 \cdot 39 \\
P=0.001^{*}\end{array}$ & $\begin{array}{l}1 \cdot 55 \pm 0.36 \\
P=0.05^{*}\end{array}$ \\
\hline Group II (24) & $\begin{array}{l}2.47 \pm 0.74 \\
P=0.001^{*}\end{array}$ & $\begin{array}{l}7 \cdot 50 \pm 2 \cdot 38 \\
P=0 \cdot 001^{*}\end{array}$ & $\begin{array}{l}0.64 \pm 0.63 \\
P=0.001^{*}\end{array}$ \\
\hline Group III (10) & $\begin{array}{l}2.01 \pm 0.63 \\
P=0.001^{*}\end{array}$ & $\begin{array}{l}6 \cdot 00 \pm 2 \cdot 00 \\
P=0.001^{*}\end{array}$ & $\begin{array}{l}0.78 \pm 0.74 \\
P=0.01^{*}\end{array}$ \\
\hline C. bifermentans (7) & $8 \cdot 08 \pm 4 \cdot 17$ & $12 \cdot 64 \pm 1 \cdot 67$ & $3.45 \pm 1.33$ \\
\hline
\end{tabular}

* Values significantly different from C. bifermentans. 
Table 5. DNA homologies of C. sordellii and C. bifermentans strains with C. sordellii IP82 and NCIB 10717, and C. bifermentans ATCC 638

The results are mean percentage homologies \pm SEM, with the range in parentheses.

\begin{tabular}{|c|c|c|c|c|}
\hline Unlabelled DNA & ${ }^{3} \mathrm{H}$-labelled DNA. & $\begin{array}{l}\text { C. sordellii } \\
\text { IP82 }\end{array}$ & $\begin{array}{c}\text { C. sordellii } \\
\text { NCIB } 10717\end{array}$ & $\begin{array}{l}\text { C. bifermentans } \\
\text { ATCC } 638\end{array}$ \\
\hline \multicolumn{5}{|l|}{ C. sordellii } \\
\hline All 43 strains & & $70 \pm 14(49-101)$ & $80 \pm 15(52-105)$ & $31 \pm 6(17-45)$ \\
\hline Group I (6) & & $86 \pm 26(56-101)$ & $89 \pm 14(61-103)$ & $31 \pm 5(26-37)$ \\
\hline Group II (26) & & $72 \pm 10(62-93)$ & $80 \pm 16(52-105)$ & $33 \pm 6(17-45)$ \\
\hline Group III (11) & & $63 \pm 11(49-81)$ & $76 \pm 13(56-93)$ & $25 \pm 3(20-29)$ \\
\hline C. bifermentans (6) & & $26 \pm 2(24-28)$ & $30 \pm 5(25-34)$ & $81 \pm 11(71-87)$ \\
\hline C. difficile ATCC 9689 & & 15 & 13 & 15 \\
\hline
\end{tabular}

The $C$. difficile type strain ATCC 9689 was clearly different from the $C$. sordellii and $C$. bifermentans strains. This strain did not sporulate in TGY broth, did not exhibit lecithinase or urease activity; did not produce indole but did hydrolyse aesculin, was gelatinase positive and fermented glucose and fructose. The fermentation end products in TYG broth were acetic, propionic, isobutyric, butyric, isovalerianic, valerianic, isocaproic, pyruvic, lactic, phenylacetic and 3-phenylpropionic acids. The enzyme activity pattern with API-ZYM tests was slightly different from those obtained with the $C$. sordellii and $C$. bifermentans strains (Table 2).

All the $C$. sordellii and $C$. bifermentans strains, and the one $C$. difficile strain, produced an unknown component in GLC with a retention time between those for caproic and heptanoic acids. Some $C$. sordellii and $C$. bifermentans strains, and the $C$. difficile strain, produced a low amount $(0 \cdot 10-0 \cdot 20 \mathrm{~mm})$ of heptanoic acid.

\section{DNA-DNA homologies}

DNAs from all the putative $C$. sordellii strains tested, including lecithinase-negative strains, showed high homologies with DNA from the $C$. sordellii type and reference strains (lowest value $49 \%$ ), whereas DNAs from the C. difficile and C. bifermentans strains tested had low homologies $(<30 \%)$ with DNA from the $C$. sordellii type and reference strains. DNAs from the $C$. bifermentans isolates showed high homologies $(>70 \%)$ with DNA of the C. bifermentans type strain, whereas $C$. difficile DNA showed very low homology $(<15 \%)$ with all the type strains (Table 5).

\section{Polyacrylamide gel electrophoresis patterns}

EDTA-extracted proteins of all the $C$. sordellii strains showed similar electrophoretic patterns, different from those obtained with the $C$. bifermentans or $C$. difficile strains. Our $C$. bifermentans isolates had slightly different electrophoretic patterns compared to the $C$. bifermentans type strain ATCC 638 (Fig. 1).

\section{DISCUSSION}

Our results are in agreement with those of Tataki \& Huet (1953), Brooks \& Epps (1958), Nishida et al. (1964), Novotny (1969) and Nakamura et al. (1975), who showed that $C$. sordellii and $C$. bifermentans are two distinct but related species and that urease activity is a useful criterion for their differentiation. However, Nakamura et al. (1976) did find urease-negative $C$. sordellii strains. Acid production from aesculin, maltose, mannose, ribose, salicin and sorbitol enabled us to distinguish $C$. sordellii, $C$. bifermentans and $C$. difficile strains, but some strains showed weak reactions that were difficult to interpret (Table 3). All the C. bifermentans strains we tested hydrolysed aesculin, and all the $C$. sordellii strains did not hydrolyse this substrate. The interpretation of this reaction was easy in all cases. In our study, quantitative GLC and SDSPAGE patterns were useful additional characters for differentiating $C$. sordellii from $C$. 


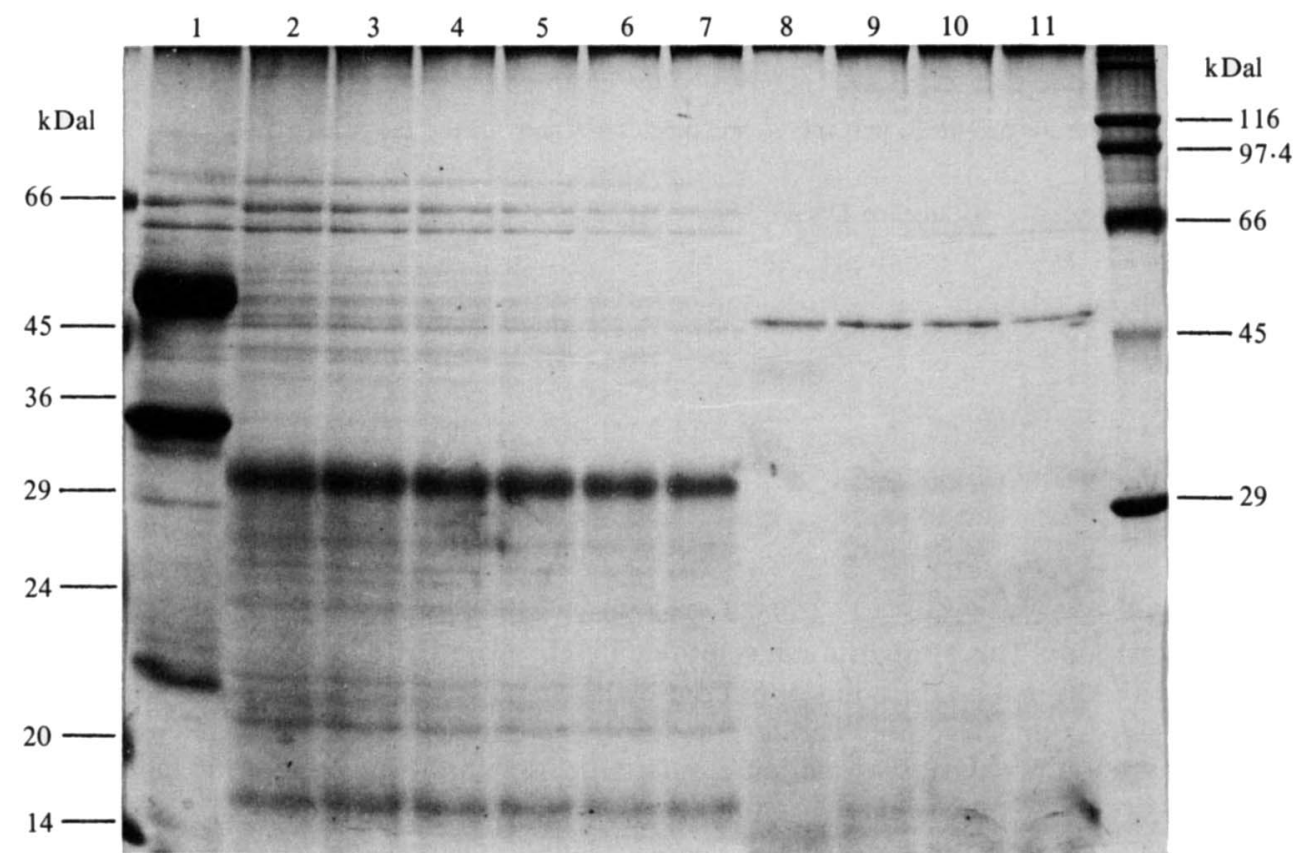

Fig. 1. Patterns of EDTA-extracted proteins from $C$. sordellii, $C$. bifermentans and $C$. difficile strains in SDS-PAGE on a $12 \%$ acrylamide gel stained with Coomassie blue. Lane 1, C. difficile ATCC 9689; lanes 2 and 3, non-pathogenic C. sordellii NCIB 10717 and CSAl respectively; lanes 4 and 5, pathogenic $C$. sordellii IP82 and CS1744 respectively; lanes 6 and 7, lecithinase-negative $C$. sordellii CS4447 and CS2089C respectively; lanes 8 to 11, C. bifermentans (ATCC 638, CBR1, CBR5 and CB1791 respectively. Moleculer weight markers are shown at the sides of the photograph.

bifermentans. Cato et al. (1982) also showed different electrophoretic pattens for these two Clostridium species for total protein extracts run in the absence of SDS.

The lecithinase-negative non-pathogenic $C$. sordellii strains we studied shared all the other phenotypic characteristics defining classical pathogenic and non-pathogenic $C$. sordellii strains, including GLC patterns of fermentation products (Holdeman et al., 1977; Sebald \& Brefort, 1977). The production of phenylacetic acid by Clostridium spp. was previously reported by Mayrand \& Bourgeau (1982). Their enzyme activity profiles using API-ZYM tests were closely related to those of lecithinase-positive $C$. sordellii strains, and were similar to those obtained by Mead et al. (1981). No significant differences in protein PAGE patterns were found between the C. sordellii strains tested. Moreover, DNA-DNA homologies confirmed that these lecithinasenegative, urease-positive and proteolytic Clostridium strains belonged to the $C$. sordellii homology group. Thus the only significant difference between these and the other $C$. sordellii strains was the lack of lecithinase activity.

C. sordellii is occasionally associated with gas gangrene in man (Willis, 1977) and animals (Smith et al., 1962), and it has recently been isolated from lambs (Richards \& Hunt, 1982), sheep (Al Mashat \& Taylor, 1983a; Popoff, 1984) and cattle (Al Mashat \& Taylor, 1983b) with enteric pathology. It is also often encountered in cases of sudden death in animals in France (unpublished). The majority of these isolates did not produce lethal toxin for mice. In our study, the lecithinase-negative $C$. sordellii stains were isolated mainly from sheep, but also from cattle, horse, goat, duck, wild animals and man. The clinical and epidemiological significance of these biovars of $C$. sordellii has yet to be established.

The authors are very grateful to M. Y. Popoff (Service des Enterobactéries, Institute Pasteur) for his assistance in performing the DNA hybridization and preparing the manuscript, and to Professor $M$. Sebald for her support during the course of this work. 


\section{REFERENCES}

Al Mashat, R. R. \& Taylor, D. J. (1983a). Clostridium sordellii in enteritis in an adult sheep. Veterinary Record 112, 19.

Al Mashat, R. R. \& Taylor, D. J. (1983b). Bacteria in enteric lesions of cattle. Veterinary Record 112,5 10.

BeErens, H. (1954). Amélioration des techniques d'étude et d'identification des bactéries anaérobies. Annales de l'Institut Pasteur de Lille 6, 36-52.

Brenner, D. J., Fanning, G. R., Skerman, F. J. \& FALKOW, S. (1972). Polynucleotide sequence divergence among strains of Escherichia coli and closely related organisms. Journal of Bacteriology 109, 953965.

Brenner, D. J., Steigerwalt, A. G., Falcao, D. P., WEAVER, R. E. \& FANNING, G. C. (1976). Characterization of Yersinia enterocolitica and Yersinia pseudotuberculosis by deoxyribonucleic acid hybridization and by biochemical reactions. International Journal of Systematic Bacteriology 26, 180-194.

Brooks, M. E. \& EpPs, H. B. G. (1958). Taxonomic studies of the genus Clostridium: Cl.bifermentans and Cl. sordellii. Journal of General Microbiology 21, 144 155.

Carlier, J. P. (1985). La chromatographie en phase gazeuse des produits de fermentation: son application dans le diagnostic des bactéries anaérobies. Bulletin de l'Institut Pasteur, Paris 83, 57-69.

Cato, E. P., Hash, D. E., Holdeman, L. V. \& Moore, W. E. C. (1982). Electrophoretic study of Clostridium species. Journal of Clinical Microbiology 15, 688-702.

Crosa, J. H., Brenner, D. J. \& Falkow, S. (1973). Use of a single-strand specific nuclease for analysis of bacterial and plasmid deoxyribonucleic acid homo- and heteroduplexes. Journal of Bacteriology 115, 904-911.

Grimont, P. A. D., Popoff, M. Y., Grimont, F., Coynault, C. \& Lemelin, M. (1980). Reproducibility and correlation study of three deoxyribonucleic acid hybridization procedures. Current Microbiology 4, 325-330.

Holdeman, L. V., Cato, E. P. \& Moore, W. E. C. (1977). Anaerobe Laboratory Manual, 4th edn. Blacksburg, Va.: Virginia Polytechnic Institute and State University.

LAEMMLI, U. K. (1970). Cleavage of structural proteins during the assembly of the head of bacteriophage T4. Nature, London 227, 680-685.

Mayrand, D. \& Bourgeau, G. (1982). Production of phenylacetic acid by anaerobes. Journal of Clinical Microbiology 16, 747-750.

Mead, G. C., Paez de Leon, L. \& Adams, B. W. (1981). A study of rapid and simplified confirmatory tests for Clostridium perfringens. Journal of Applied Bacteriology 51, 355-361.
Nakamura, S., Shimamura, T., Hayashi, H. \& NisHidA, S. (1975). Reinvestigation of the taxonomy of Clostridium bifermentans and Clostridium sordellit. Journal of Medical Microbiology 8, 299-309.

Nakamura, S., Shimamura, T. \& Nishida, S. (1976). Urease-negative strains of Clostridium sordellii. Canadian Journal of Microbiology 22, 673676.

Nishida, S., TAmai, K. \& Yamagishi, T. (1964). Taxonomy of Clostridium bifermentans and Clostridium sordellii. 1. Their toxigenicity, urease activity, and sporulating potency. Journal of Bacteriology $\mathbf{8 8}$, 1641-1646.

Novotny, P. (1969). Composition of cell walls of Clostridium sordellii and Clostridium bifermentans and its relation to taxonomy. Journal of Medical Microbiology 2, 81-100.

POPOFF, M. R. (1984). Bacteriological examination in enterotoxaemia of sheep and lambs. Veterinary Record 114, 324

Popoff, M. Y. \& Coynault, C. (1980). Use of DEAEcellulose filters in the $S 1$ nuclease method for bacterial deoxyribonucleic acid hybridization. $\mathrm{An}$ nales de microbiologie 131A, 151-155.

Poxton, I. R. \& BYRNE, M. D. (1981). Immunological analysis of the EDTA-soluble antigens of Clostridium difficile and related species. Journal of General Microbiology 122, 41-46.

Poxton, I. R. \& Byrne, M. D. (1984). Demonstration of shared antigens in the genus Clostridium by an enzyme-linked immunosorbent assay. Journal of Medical Microbiology 17, 171-176.

RichaRd, S. M. \& HUNT, B. W. (1982). Clostridium sordellii in lambs. Veterinary Record 111, 22.

Rifkin, G. D., Fekety, F. R., Silva, J. \& SACK, R. B. (1977). Antibiotic-induced colitis: implication of a toxin neutralized by Clostridium sordellii antitoxin. Lancet ii, 1103-1106.

SEbald, M. \& BREForT, G. (1977). Recherche et identification des anaérobies en bactériologie courante. Revue du praticien 27, 107-118.

Skerman, V. B. D., McGowan, V. \& Sneath, P. H. A. (1980). Approved lists of bacterial names. International Journal of Systematic Bacteriology 30, 225-240.

Smith, L. D., Safford, J. W. \& Hawkins, W. W. (1962). Clostridium sordellii infection in sheep. Cornell Veterinarian 52, 62-68.

TATAKI, H. \& HUeT, M. (1953). Valeur du test de l'uréase pour la différenciation de Clostridium sordellii et Clostridium bifermentans. Annales de l'Institut Pasteur 84, 890

WILLIS, A. T. (1977). Characteristics of the pathogenic and related clostridia. In Anaerobic Bacteriology: Clinical and Laboratory Practice, 3rd edn, pp. 111172. London: Butterworths. 